\title{
İslami Finansal Kuruluşlar İçin Muhasebe Standartları ve Uluslararası Muhasebe Standartlarının Karşılaştırmalı Olarak Analizi*
}

\section{Comparative Analysis of International Accounting Standards for Islamic Financial Institutions and Accounting Standards}

\author{
İbrahim Çemberlitaş ${ }^{\text {a,** }}$, Tolga Oral ${ }^{\mathrm{b}}$, Hakan Erkuş ${ }^{\mathrm{c}}$ \\ ${ }^{a}$ Arş. Gör. Dr.. Dicle Üniversitesi, İktisadi ve İdari Bilimler Fakültesi, İşletme Bölümü, 21200, Diyarbakır/Türkiye. \\ ORCID: 0000-0002-2489-9060

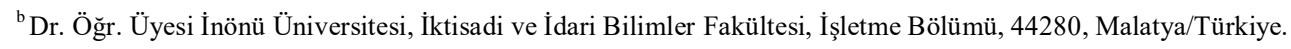 \\ ORCID: 0000-0002-7173-8171
}

${ }^{\text {c } P r o f . ~ D r ., ~ I ̇ n o ̈ n u ̈ ~ U ̈ n i v e r s i t e s i, ~ I ̇ k t i s a d i ~ v e ~ I ̇ d a r i ~ B i l i m l e r ~ F a k u ̈ l t e s i, ~ I ̇ s ̧ l e t m e ~ B o ̈ l u ̈ m u ̈, ~ 44280, ~ M a l a t y a / T u ̈ r k i y e . ~}$ ORCID: 0000-0003-0925-9396

\begin{tabular}{l} 
MAKALE BİLGİṠ் \\
\hline Makale Geçmişi: \\
Başvuru tarihi: 01 Nisan 2020 \\
Düzeltme tarihi: 28 Haziran 2020 \\
Kabul tarihi: 06 Temmuz 2020 \\
Anahtar Kelimeler: \\
AAOIFI, \\
UFRS, \\
UMSK \\
Uluslararası Muhasebe Standartları
\end{tabular}

\section{ART ICLEINFO}

\section{Article History:}

Received 01 April 2020

Received in revised form 28 June 2020 Accepted 06 July 2020

\section{Keywords:}

AAOIFI,

IFRS,

IASB,

International Accounting Standards

\begin{abstract}
ÖZ
Küreselleşme ile birlikte ticari işlem sayılarının artması Dünya'da ortak bir finansal raporlama dilinin gerekliliğini ortaya çıkarmıştır. Uluslararası Finansal Raporlama Standartları (IFRS) bu ihtiyaç üzerine ortaya çıkmıştır. Benzer şekilde diğer ortak bir dil ve standart ihtiyacı da İslami Finansal Kurumlar için Muhasebe ve Denetim Standartları Organizasyonu (AAOIFI) için gerekli olmuştur. Zira Müslümanlar, dünya üzerinde azımsanmayacak bir nüfusa sahiptir. Müslüman ülkelerin finansal faaliyetlerini dini kurallara göre yapma gereksinimleri en tabii haklarıdır. Bu hakkın somut bir sonucu olarak ve bir ihtiyaç üzerine ortaya çıkan AAOIFI de bu anlamda finansal işlemlerin dini kurallar gereği yapılmasına olanak tanımıştır. Bu çalışmanın amacı, bu iki standardın birbirleriyle karşılaştırılması, benzerlik ve farklılıklarının ortaya konulmasıdır. Kavramsal çerçeve, kiralamalar, fon kullandırma, ortaklıklar ve inşaat sözleşmeleri standartlarının karşılıklı incelenmesi amaçlanmıştır. Bu amaç doğrultusunda kavramsal bir inceleme yapılarak, Türkiye özelinde Dünya'daki uygulamalara yer verilmiştir.
\end{abstract}

\section{A B S T R A C T}

The increase in the number of commercial transactions with the globalization has revealed the necessity of a common financial reporting language in the World. The International Financial Reporting Standards (IFRS) have been introduced on this need. Similarly, the need for another common language and Standard has also been required for accounting and Auditing Standards (AAOIFI) for Islamic Financial Institutions. Because Muslims have a considerable population in the world. Muslim countries have the most natural right to carry out financial activities of with religious rules. As a result of this right and upon a need, the AAOIFI also allowed financial transactions to be carried out in accordance with religious rules. The aim of this study is to compare these two standards and to reveal their similarities and differences, the conceptual framework, leases, fund utilization, partnerships and construction contracts are aimed at mutual examination of the standards.In line with this objective by making a conceptual study, Turkey is given to private practice in the world.

\section{Giriş}

Uluslararası Finansal Raporlama Standartları (International Financial Reporting Standards - IFRS) ülkelerin farklı muhasebe anlayışlarının farklılığını gidermek üzere yayımlanan standartlardır. Uluslararası Muhasebe Standartları Kurulu (Internatioanal Accounting Standards Board - IASB) tarafindan çıkarılan bu standartların temel amacı muhasebe ve muhasebeleştirme sürecine şeffaf, anlaşılabilir, karşılaştırılabilir bir ortak dil gerekliliğinden

*Bu çalışma 10-12 Ekim 2019 tarihlerine Diyarbakır'da düzenlenen 3.ISEPA sempozyumunda sunulan ve tam metni yayınlanan bildirinin genişletilmiş şeklidir.

** Sorumlu yazar/Corresponding author

e-posta: drcemberlitas@gmail.com 
ibarettir. Uluslararası ticaretin artması muhasebe kayıt işlemleri ile ilgili bir karmaşıklı̆̆ı da beraberinde getirmiştir. Bu karmaşıklığın çözümü konusunda IFRS uluslararası ticaret yapan işletmelerin muhasebe birimlerine bu anlamda yardımcı olan bir süreçtir. Zira IASB'nin standartlardan önce yayınladı̆̆ı kavramsal çerçeveye bakıldığında zikredilen karmaşıklık ve farklılık şu şekilde ifade edilmiştir:

"Bir takım sosyal, ekonomik ve hukuki sebepler ile ulusal düzenlemelerin oluşturulması sirasında farklı ülkeler tarafindan farkl finansal tablo kullanicılarinin gereksinimlerinin dikkate alınmast gibi sebeplerle de bazı farklılıklar taşımaktadır"(KGK, Finansal Raporlamaya İlişkin Kavramsal Çerçeve, 2011: 1).

IFRS ortak dil olmanın yanı sıra kurulun aldığı karar ile karşılaştırılabilir olması için şeffaflık ilkesini de içinde barındıran standartlardır. $\mathrm{Bu}$ şeffaflık sayesinde finansal tablo kullanıcılarının alacağı bir yatırım kararında doğru bilgiye ulaşabilmekte ve karar vermek süreci daha net ve kolay olmaktadır.

Son dönemlerde gerek dünyada gerekse Türkiye'de AAOIFI standartlarına ilişkin çalışmaların olduğunu görmek mümkündür.

Özulucan ve Deran (2009) katılım bankacılığını ve geleneksel bankacılık hizmetlerini muhasebe uygulamaları açısından karşılaştırarak incelemişlerdir. Çalışmalarının sonucunda katılım bankalarının geleneksel bankalarla rekabet edebilmek ve atıl fonları ekonomiye kazandırabilmek için çeşitli yöntemler geliştirmeleri gerektiğini vurgulamışlardır. Çalışmalarında muhasebe uygulamalarındaki farklılıkları belirtmek için şu örneği vermişlerdir:

"Örneğin; bankalar faizi esas alarak faaliyetlerini sürdürdükleri için devlet tahvili, hazine bonosu, repo ve Interbank işlemleri gibi alım-satım işlemlerini yapabilirlerken; katılım bankaları çalışma prensipleri gereği, bu işlemleri ve bu işlemlerden kaynaklanan kimi yasal yükümlülükleri (örneğin; BSMV) yerine getirmemektedirler."

Erkuş ve Çenberlitaş (2016), çalışmalarında Sukuk'ların muhasebeleştirilmesine dair örnek çalışmalara yer vermişlerdir. Çalışmalarında birçok İslam ülkesinde muhasebe ve denetleme kurumunun bulunduğu ve bu kurumların çıkardığı standartlara göre İslami finansal araçların kayıtlarının yapıldığını belirtmişlerdir.

Yardımcıoğlu (2016), icare işlemlerinin ve klasik uygulamalardaki finansal kiralama işlemlerinin muhasebeleştirme süreçlerini farklı muhasebe standartları bağlamında incelemiştir.

Ağkan (2018), yaptığı çalışmada AAOIFI standartlarının Türkiye'de uygulanabilirliğini araştırmıştır. $\mathrm{Bu}$ anlamda Türkiye'de Kamu Gözetimi Muhasebe ve Denetim Standartları Kurumunun (KGK) standartlar ile ilgili yaptığı çalışmalar incelenmiştir.

Ersoy, Çatıkkaş ve Yatbaz (2018) yaptıkları çalışmada İslami muhasebeyi geleneksel muhasebe çerçevesinde inceleyip bunun akabinde teorik bir çerçeve ortaya koymaya çalışmışlardır. İstanbul'un bir finans merkezi olması yolundaki gelişmelerin paralelinde İslami bankacılık ve finansa da daha fazla önem verilmesi gerektiğini belirtmişlerdir.

$\mathrm{Bu}$ çalışmada AAOIFI'nin yayımladığı muhasebe standartları ile IASB'nin yayımladığı muhasebe standartları karşılaştırmalı olarak incelenmiştir. İki standardın karşılaştırması yapılırken faizsiz finans kuruluşlarının kullandığ 1 standartlar ile faize dayalı sistemde faaliyet gösteren finansal kuruluşların kullandığı standartların benzerlikleri ve farklılıkları incelenmiştir. İşletmelerin çoğunlukla kullandığı finansman yöntemleri ile ilgili amaç, kapsam ve esaslar iki sistemde seçilmiş standartlar yolu ile karşılaştırılarak irdelenmiştir.

\section{2. İslami Finansal Kurulușlar İçin Muhasebe ve Denetim Organizasyonu (AAOIFI)}

İslami Finansal Kuruluşlar İçin Muhasebe ve Denetim Organizasyonu (Accounting and Auditing Organization for Islamic Financial Institution - AAOIFI) Manama / Bahreyn merkezli bir kuruluştur. IASB'nin dünyadaki ticari işlemlerin muhasebe işlemleri için ortak dil olan IFRS'1 yayımladığı gibi AAOIFI de başta İslami bankalar olmak üzere İslami finansal kuruluşların muhasebe işlemlerinde ortak bir dil olan standartları yayımlamaktadır. 1990 yılında kurulan AAOIFI İslami finans kurumları, katılımcıları ve tüm sektöre yönelik Şeriat standartlarını korumak ve desteklemek amacıyla kurulan kar amacı gütmeyen bir organizasyondur. Kuruluşundan bu yana Şer’i Standartlar, Denetim Standartlar1, Yönetim Standartları, Etik Standartları ve Muhasebe Standartları olmak üzere 5 farklı alanda standartlar yayımlamıştır.

Türkiye'de şer'i standartları Türkiye Katılım Bankaları Birliği (TKBB) Türkçe'ye kazandırmıştır. Bu standartlar Türkçe yayımlanan adı faizsiz finans standartları olarak finans literatürüne geçmiştir. Muhasebe standartları ise KGK bünyesinde Türkçe 'ye çevrilerek zaman zaman kamuoyunun görüşüne açılarak kısmi olarak yayımlanmaktadır. Muhasebe standartları da Türkçeye çevrilirken Faizsiz Finans Muhasebe Standartları olarak çevrilmektedir.

\subsection{Dünya'da AAOIFI'nin Gelişimi}

İlk uygulamaları 1963 yılında Mısır'da ortaya çıkmaya başlayan İslami finansal kuruluşlar sonraki yıllarda Pakistan, Malezya, Suudi Arabistan, Bahreyn gibi ülkelerde sayıca artmaya başlamışlardır. İlk zamanlar basit yöntemler ile yapilan uygulamalar daha sonra yerini modern uygulamalara bırakmışlardır.

İslami finansal sistemdeki muhasebe uygulamalarının İslami prensiplere uygun olması için belirli standartlara ihtiyaç duyuluştur. $\mathrm{Bu}$ anlamda İslami finansal kuruluşlar için çeşitli ülkelerde muhasebe standartları geliştirilmiştir. Malezya'da İslami Finansal Hizmetler Kurulu belirli muhasebe standartlarını yayınlamaya başlamışlardır. Daha sonra Pakistan'da Pakistan Yeminli Mali Müşavirler Enstitüsü bu anlamda yerel standartlar çıkarmıştır. Fakat bu ülkelerde çıkarılan standartlar ilgili ülkelerle sınırlı kalmış, uluslararası boyutlara ulaşmamıştır.

İslami finansal sistemde en yetkin ve uluslararası çaplı standart düzenleme kurulu Bahreyn'de kurulmuştur. AAOIFI adlı bu kuruluş dünya çapındaki İslami finansal 
kuruluşlar için bir muhasebe, denetim, etik vb. standartlar yayımlamaktadır.

1991 yılında kurulan ve Bahreyn merkezli AAOIFI, küresel İslami finans endüstrisi için standartların geliştirilmesi ve verilmesinden öncelikle sorumlu olan önde gelen uluslararası kar amacı gütmeyen kuruluştur. Uluslararası İslami finans için şeriat, muhasebe, denetim, etik ve yönetişim alanlarında toplam 100 standart yayınlanmıştır (AAOIFI, 2020: 1).

AAOIFI'nin bazı alanlarda yayınladığı standartlar tamamlanmış, bazı alanlarda yayınladığı standartlar da peyder pey yayınlanmaktadır. Şeriat standartlarına ilişkin 54 adet standardın tamamı 2015 yılında yayınlanmıştır. Ayrica 26 adet muhasebe standardı ve 6 adet denetim standardı da yayınlanmış bulunmaktadır.

İslami finansal kuruluşlara yönelik uluslararası düzeyde muhasebe standartları düzenleme konusunda tek otorite kabul edilen Bahreyn merkezli AAOIFI'nin yayınladığı standartlar üye ülkelerdeki yetkili kuruluşlar tarafindan kendi ülkelerinin dillerine çevrilmektedir.

\subsection{Türkiye' de AAOIFI'nin Gelişimi}

Türkiye'de İslami finans kuruluşları 1980'lerin başında faaliyet göstermeye başlamışlardır. İlk defa Özel Finans Kuruluşları ismi ile faaliyet göstermeye başlayan bu kuruluşlar 2005 yılında çıkarılan bir kanun ile "Katılım Bankası" adı ile finansal faaliyetlerini devam ettirmișlerdir. Birçok İslam ülkesinde "İslami Bankacılık" isminin kullanılmasına karşın Türkiye'de Íslam ibaresi kullanılmamıştır. Türkiye'de katılım bankalarının ve faizsiz finans kuruluşlarının kullanması için muhasebe standartlarının yayımlanması KGK'nın sorumluluğundadır.

AAOIFI tarafindan yayımlanan standartlar KGK tarafindan Türkçe'ye çevrilmekte ve KGK bünyesindeki sorumlu kurul tarafindan kontrolü gerçekleştirilmektedir. Sonrasında KGK'nın web sitesinde taslak olarak kamuoyunun ve ilgililerin değerlendirmesine sunulmaktadır. Gelen görüşler çerçevesinde standartların son halleri yayımlanmaktadır.

TKBB ve Sabahattin Zaim Üniversitesinin ortak çalışmalarıyla AAOIFI'nin yayımladığı standartlardan Şeriat Standartlarının tamamı Türkçeye çevrilmiştir. Türkçe'ye Faizsiz Finans Standartarı adıyla tercüme edilen 58 standart kitap haline getirilmiş ve TKBB'nin web sitesinde yayımlanmıştır. ${ }^{1}$ TKBB'nin bu standartları yayınlamasından sonra diğer standartlar ise KGK tarafindan Türkçe'ye çevrilmekte ve yayınlanmaktadır.

AAOIFI'nin yayınladığı Finansal Muhasebe Standartları"ndan 22 tanesi KGK tarafindan "Faizsiz Finans Muhasebe Standartları" adıyla Türkçeye çevrilmiş ve kısaltması da FFMS olarak belirlenmiştir (Çemberlitaş, 2019: 76).

\section{Uluslararası Muhasebe Standartları Kurulu (UMSK)}

Uluslararası Muhasebe Standartları Komitesi (International Accounting Standards Committee-IASC) dünyadaki ticari

\footnotetext{
${ }^{1}$ https://www.tkbb.org.tr/documents/Yonetmelikler/FAIZSI
} Z-FINANS-STANDARTLARI.pdf işlemler için ortak bir dil olan standartlar yayımlamayı ilke edinen bir yapı olarak 1973 yılında kurulmuştur. İstendiği gibi bir yapıya tam olarak ulaşamayan bu yapı daha sonra öncekinden bağımsız bir kurul olarak 2001 yılında Londra'da yapılan bir toplantı ile yeniden şekillenmiş ve Uluslararası Muhasebe Standartları Kurulu (International Accounting Standards Board-IASB) adı ile çeşitli muhasebe standartlarını yayımlamaya başlamıştır. Daha önce yayımlanan standartlar Uluslararası Muhasebe Standartları (International Accounting Standards-IAS) olarak isimlendirilmişken 2001 yılında kurulan yapıdan sonra yayımlanan standartlar Uluslararası Finansal Raporlama Standartları (International Financial Reporting Standards-IFRS) olarak isimlendirilmiştir.

Bu kapsamda TMS'ler IAS'lerin; TFRS'ler ise IFRS'lerin birebir Türkçe çevirilerini ifade etmektedir. Dolayısıyla TMS'ler ve TFRS'ler arasında bağlayıcılık açısından bir farklılık bulunmamaktadır (KGK, 2019: 1). Türkiye'de TFRS'leri yayımlamakla yetkili kurum KGK çeşitli zamanlarda yeni çıkan veya güncellenen standartları yayımlamaktadır.

IFRS işletmelerin mali bilgilerini gösteren finansal tablolarını, performanslarını ve nakit akışlarını gerçeğe uygun hazırlamaları için çıkarılan rehber niteliğindeki standartlardır. Sadece işletmelerin değil ilgililerin özellikle yatırımcıların kararlarını etkilediği için mali bilgilerin doğru aktarılmasını sağlamak da IFRS'nin başlıca amacıdır. $\mathrm{Bu}$ şekilde finansal tablolar güvenilir, karşılaştırılabilir ve anlaşılabilir olacaktır (Akgün 2013: 11).

\subsection{Dünyada UFRS'nin Gelişimi}

IFRS yüksek kalitede, anlaşılabilir, uygulanabilir ve küresel anlamda kabul görmüş muhasebe standartları geliştirmek için kurulmuş bir kuruluştur. Bunun yanında bu kuruluş yayımlanan standartlarının benimsenmesini teşvik etmek ve uygulanmasını kolaylaştırmak için kurulan ve kâr amacı gütmeyen kamu yararına kurulan bir kuruluştur. Yayımlanan IFRS'ler Uluslararası Muhasebe Standartları Kurulu (IASB) tarafindan belirlenmektedir (IFRS 2019: 1).

Amerika Birleşik Devletleri (ABD)'nin standart belirleme organı olan Finansal Muhasebe Standartları Kurulu (FASB), iki muhasebe rejimini yakınlaştırma hedefine yönelik IASB ile birlikte çalışmaya karar vermiştir. Bu noktada ABD Sermaye Piyasası Kurulu (SEC) Başkanı, Christopher Cox, Norwalk Anlaşması'nın imzalanmasıyla 18 Eylül 2002'de bu hedefe ulaşıldığını belirtmiştir. Anlaşma, mevcut standartlardaki büyük farklılıkları ortadan kaldırmayı, gelecekteki projeler üzerinde ortaklaşa çalışmayı ve standart belirleme organları arasında işbirliğini teşvik etmeyi amaçlamıştır (Trimble, 2017: 6).

2002 yılında Avrupa Birliği (AB) tarafindan, halka açık tüm şirketlerin 2005 yılı mali tablolarında Uluslararası Finansal Raporlama Standartları'na (IFRS) tabi olmalarını gerektiren bir muhasebe düzenlemesini onaylaması sonucunda, tüm dünyada özellikle de Avrupa'da yeni ve karmaşık bir dönem başlamıştır. Bu değişiklik, doğal olarak Türkiye'yi de önemli ölçüde etkilemiştir. AB'ye uyum çalışmaları içinde olan Türkiye'deki düzenleyici kuruluşlarda ardı ardına IFRS'ler ile uyum çalışmalarına başlamışlardır (Deloitte, 2019: 1). 
2000 yılı sonrası AB'de UFRS uygulamalarına ilişkin gelişmeler aşağıdaki tabloda özetlenmiştir.

\begin{tabular}{ll}
\hline 2000 & $\begin{array}{l}\text { Halka açık şirketlerin konsolide finansal tablolarını } \\
\text { IFRS'ye uygun şekilde raporlamasına ilişkin planın } \\
\text { duyurulması }\end{array}$ \\
\hline 2001 & $\begin{array}{l}\text { Gerçeğe uygun değerle muhasebeleştirme yönergesi } \\
\text { (özellikle finansal araçlar için) }\end{array}$ \\
\hline 2002 & $\begin{array}{l}\text { Uluslararası muhasebe standartlarına uygun } \\
\text { raporlama düzenlenmesi (2005 yılı itibariyle IFRS } \\
\text { uygulanması) }\end{array}$ \\
\hline 2003 & \begin{tabular}{l} 
Çağdaşlaşma yönergesi (IFRS gelişmeleri) \\
\hline 2005 -
\end{tabular} \\
$\begin{array}{l}\text { AB ülkelerinde halka açı şirketlerin IFRS'ye uygun } \\
\text { raporlama yapması }\end{array}$ \\
\hline
\end{tabular}

Kaynak: (UFRS/IFRS, 2015: 1)

Aşağıdaki tabloda 2005 yılına kadar yıllar itibariyle dünyada ve $A B$ ülkelerinde IFRS uygulayan şirket sayısı görülmektedir.

\begin{tabular}{cccccccc}
\hline & Dünya & $\begin{array}{c}\text { AB ve } \\
\text { İsviçre }\end{array}$ & $\begin{array}{l}\text { UFRS } \\
\%\end{array}$ & Almanya & İsviçre & Avusturya & $\begin{array}{c}\text { UFRS } \\
(3 \text { Ülke) } \%\end{array}$ \\
\hline 1996 & 207 & 103 & $50 \%$ & 11 & 74 & 0 & $41 \%$ \\
\hline 1997 & 271 & 143 & $53 \%$ & 26 & 83 & 4 & $42 \%$ \\
\hline 1998 & 325 & 182 & $56 \%$ & 49 & 87 & 9 & $45 \%$ \\
\hline 1999 & 443 & 257 & $58 \%$ & 100 & 92 & 23 & $49 \%$ \\
\hline 2000 & 679 & 402 & $59 \%$ & 176 & 131 & 39 & $51 \%$ \\
\hline 2001 & 777 & 467 & $60 \%$ & 202 & 141 & 47 & $50 \%$ \\
\hline 2002 & 831 & 525 & $63 \%$ & 232 & 152 & 61 & $54 \%$ \\
\hline 2003 & 858 & 536 & $62 \%$ & 243 & 139 & 58 & $51 \%$ \\
\hline 2004 & 828 & 538 & $65 \%$ & 256 & 122 & 50 & $52 \%$ \\
\hline
\end{tabular}

Kaynak: (ufrs/ifrs, 2015: 1)

\subsection{Türkiye' de UFRS'nin Gelişimi}

Uluslararası Finansal Raporlama Standartlarını Türkiye'de tercüme etmeye yetkili kuruluş olan Türkiye Muhasebe Standartları Kurulu (TMSK) bu standartların tamamını tercüme etmiştir. Türkçeye Türkiye Finansal Raporlama Standartları olarak çevrilen bu standartların kısaltılması da TFRS olarak belirlenmiştir. TFRS'den önce Sermaye Piyasası Kurulu (SPK) tarafindan yayımlanan standartlar kullanılmaktaydı ve esasen UFRS'den çok fazla farkı yoktu. Benzer şekilde daha önce Maliye Bakanlığı'nın hazırlayıp yayımladığı Tek Düzen Muhasebe Standartları'nın yerini de UFRS almıştır (Aysan, 2007: 54).

Türkiye'de Uluslararası Finansal Raporlama Standartlarına dair ilk ciddi teşebbüs Türkiye Muhasebe Uzmanları Derneği'nin (TMUD) bu standartları Türkçeye çevirmesi ile başlamıştır. Daha sonra TÜRMOB bünyesinde tecrübeli muhasebe bilim insanlarının katkılarıyla oluşturulan Türkiye Muhasebe ve Denetim Standartları Kurulu (TMUDESK) 19 adet standardı Türkçeye çevirerek yayımlamıştır. Standartları yayımlamaktaki yasal eksiklikler sebebiyle adı geçen kurullar uzun süre faaliyet gösterememiştir (Üstünel, 2003: 3). 1999 yılında 2499 sayılı Sermaye Piyasası Kanunu'nda değişiklik yapan 4487 sayılı kanun yayımlanarak bu yasal eksiklik giderilmiştir.

4487 sayılı kanun ile kamu tüzel kişiliğini haiz ve idari ve mali özerkliğe sahip Türkiye Muhasebe Standartları Kurulu (TMSK) kurulmuştur. 1999 yılından 2011 yılına kadar Türkiye'de daha önce Uluslararası Muhasebe Standartlarını
(UMS) ve 2001 yılından sonra da Uluslararası Finansal Raporlama Standartlarını (UFRS) TMSK yayımlamıştır. Daha sonra Türk Ticaret Kanunu uyarınca öngörülen bağımsız denetim alanını düzenlemek üzere 660 sayılı Kanun Hükmünde Kararname (KHK) ile 2 Kasım 2011 tarihinde Kamu Gözetimi Muhasebe ve Denetim Standartları Kurumu (KGK) kurulmuştur. KGK'nın kurulmasindan bu yana finansal raporlama standartları bu kurum tarafindan yayınlanmaktadır.

\section{AAOIFI ve UMSK Karşılaştırması}

AAOIFI standartları İslami finansal kuruluşlar için yayımlanan standartlar olduğu gibi UFRS'de geleneksel sistemde faaliyetlerini yürüten işletmeler için de yayımlanan standartlardır. Bu başlık altında iki standarda ve standartları yayımlayan kurumların yapılarına karşılaştırmalı olarak yer verilmiştir.

\section{1. İslami Finansal Kuruluşlar İçin Muhasebe ve Denetim Organizasyonu'nun (AAOIFI) Yap1s1}

AAOIFI'nin organizasyon yapısına bakıldığında genel kurulun altında bazı kurulların olduğu görülür. $\mathrm{Bu}$ genel kurulda 15 ülkeden katılan elliden fazla kurum yer almaktadır. Genel kurulun altında mütevelli heyeti, muhasebe ve denetim standartları kurulunu yanı sıra bir de şeriat kurulu bulunmaktadır. Muhasebe ve denetim kurulunda 15 part-time üye ve ayrı bir birim olan şeriat kurulunda ise 4 part-time üye bulunmaktadır. Bunlarla beraber İcra Komitesi ve tam zamanlı yürütme ve genel sekreteri bulunan bir genel sekreterliği bulunmaktadır (Abdel-Karim, 1999: 240).

AAOIFI'nin örgütsel yapısının şekillenmesine öncülük eden gruplardan bazıları İslam Kalkınma Bankası, Kuwait Finance House, Dallah Albaraka Group, Al Rajhi Banking \& Investment Corporation, Dar-al Maal Islami gibi İslami finansal kuruluşlardır (Aktepe ve Odabaşı 2012: 38).

AAOIFI 45'ten fazla ülkede merkez bankaları, düzenleyici otoriteler, finansal kurumlar, muhasebe ve denetim firmaları ve ülkelerdeki diğer yasal firmalar gibi bir dizi kurumlarca desteklenmektedir. Standartları şu anda dünya çapında tüm önde gelen İslami finans kurumları tarafindan takip edilmekte ve uluslararası İslami finans uygulamaları gayet ileri bir derecede yer almış bulunmaktadır (AAOIFI, 2020).

\subsection{UMSK'nin Yapis1}

IASB'nin üzerinde IFRS (üst) kuruluşu oluşturulmuştur. IFRS kuruluşu; IASB'nin üyelerinin atanması, faaliyetlerinin gözetimi, etkinliğinin gözden geçirilmesi ve finansmanı konularından sorumludur. IFRS mütevelli heyeti üyelerinin atanması ve faaliyetlerin izlenmesi, Gözetim Kurulu (Monitoring Board) tarafindan gerçekleştirilmektedir. Monitoring Board ilgili ülkelerin sermaye piyasası otoriteleri tarafindan teşkil edilmektedir. Standartların belirlenmesi ve yayımlanması görevi IASB'ye ait olup, standartların yorumlanması için ayrıca IFRS Yorum Komitesi (IFRICs) kurulmuştur. IASB, uluslararası finansal raporlama ve küçük ve orta ölçekli işletmelerin muhasebe standartlarının (SMEs) geliştirilmesinden sorumludur. 


\section{Seçilmiş Standartlar Çerçevesinde AAOIFI- UFRS Karșılaștırılması}

\subsection{Kavramsal Çerçeve}

\subsubsection{AAOIFI Kavramsal Çerçeve}

AAOIFI standartlarına dair kavramsal çerçeve şu şekilde belirlenmiştir: "Kavramsal Çerçeve, Faizsiz Finans Kuruluşlarının (FFK) muhasebe uygulamaları ile FFK'ler tarafindan yapılan finansal raporlamanın temel amaçlarını ve kavramlarını belirler. Finansal muhasebe ve finansal raporlamanın amacı, Kavramsal Çerçevenin temelini teşkil eder. Kavramlar amaçlardan kaynaklanır ve finansal raporlamaya ilişkin ilkelerin bir çerçevesini temsil eder." (KGK, AAOIFI Kavramsal Çerçeve, 2019: 1).

Finansal muhasebe ve finansal raporlamanın amaçları, kullanıcıların bu raporlara dayanarak karar almasına yardımcı olmak amaciyla finansal raporlarda yer verilmesi gereken bilgilerin türünü ve niteliğini belirler. Dolayısıyla, finansal muhasebenin amaçları, finansal rapor kullanıcılarının ortak bilgi ihtiyaçlarına odaklanmalıdır. Bunun için öncelikle FFK tarafindan kullanıcılar belirlenmelidir. Buna ek olarak bu amaçlar, ihtiyaç duyduğu bilgiyi doğrudan elde etme yetki ve imkânına sahip olmayan ya da bilgiye erișimi olmayan kullanıcıların ortak bilgi ihtiyaçlarına odaklanır. Bu odak iki nedenden kaynaklanır (Kamu Gözetimi Muhasebe ve Denetim Standartları Kurumu -KGK-, AAOIFI Kavramsal Çerçeve, 2019: 4):

$\checkmark \quad$ Diğer kullanıcıların karar almak için ihtiyaç duyduğu bilgiyi doğrudan FFK'den elde etme yeteneği ve

$\checkmark \quad$ Muhasebecilerin finansal raporlara dâhil edebileceği bilgilerin sınırlı bir yapıya sahip olması nedeniyle farklı kullanıcıların bilgi ihtiyaçlarının çeşitliliği arasında seçim yapma ihtiyacı.

\subsubsection{UFRS Kavramsal Çerçeve}

Kavramsal Çerçeve, genel amaçlı finansal raporlamanın amacını ve bununla ilgili kavramları tanımlamaktadır (KÇ). Kavramsal çerçeve, finansal raporlamaya ilişkin genel bilgiler sunarak finansal tablolarda raporlanacak bilgilerin anlaşılması ve yorumlanmasına katkı sağlamaktadır. $\mathrm{Bu}$ açılardan bakıldığında kavramsal çerçeve bir standart olmayıp, genel anlamda standartların anlaşılması ve uygulanmasında tüm kesimlere önemli bir yol gösterici olmaktadır. Yeni bir standardın ortaya çıkması ya da özel bir standardın olmadığı durumlarda kavramsal çerçeve bu boşluğu doldurmaktadır. Kavramsal Çerçevenin standart uygulama aşamalarında yol gösterici bir rolünün olduğu ifade edilebilir. $\mathrm{Bu}$ nedenle standartları yorumlayıp uygulayabilmek için kavramsal çerçeveyi iyi özümsemek oldukça önem arz etmektedir (Çelik ve Turan, 2019: 9394).

Kavramsal Çerçevede, genel amaçlı finansal raporlamanın amacı, faydası, özellikleri gibi hususlar açıklanmaktadır. Bu nedenle finansal tablolarda yer alan bilgilerin ne tür özellikler taşıması ya da hangi bilgilerin finansal tablolarda sunulması gerektiği kavramsal çerçevede yer almaktadır. $\mathrm{Bu}$ bilgiler finansal tablolarda yer alan bilgilerin anlaşılabilirliğini ve finansal tablo kullanıcılarının verecekleri kararlarda isabetliliği arttırmaktadır. "Genel amaçlı finansal raporlamanın amacı, mevcut ve potansiyel yatırımcılar, borç verenler ve kredi veren diğer taraflara, raporlayan işletme hakkında o işletmeye kaynak sağlamaya iliş̧kin kararlar verirken faydalı olacak finansal bilgiyi sağlamaktır" (KGK, Kavramsal Çerçeve, 2018: 1). Bu nedenle finansal tablolar düzenlenirken bu amaç göz önünde bulundurulmalıdır.

Kavramsal çerçevede yer alan ya da açılanan bir diğer önemli husus da finansal tablolarda yer alacak bilgilerin hangi özellikleri taşıması gerektiğidir. Finansal bilginin temel niteliksel ve destekleyici niteliksel özelliklerinden bahsedilmektedir. Temel niteliksel özellikler finansal bilginin olmazsa olmaz özellikleridir. Bu özellikler finansal bilginin faydası arttırmaktadır. Bir bilginin faydalı finansal bilgi olabilmesi için ihtiyaca uygun ve gerçeğe uygun sunulması gerekmektedir. Bu iki temel niteliksel özellik, finansal bilgi için elzemdir. Bunların dışında finansal bilginin, karşılaștırılabilir, anlaşılabilir, doğrulanabilir ve zamanında sunulması gibi özellikleri de bulunmaktadır. Bunlar da destekleyici niteliksel özellikler olarak ifade edilmektedir. Bu özellikler faydalı finansal bilginin faydası arttırmaktadır. Ancak bu özelliklerin var olması tek başına finansal tablolarda yer almasına yeterli değildir. Temel niteliksel özellikleri taşımayıp destekleyici niteliksel özellikleri taşımanın bir anlamı bulunmamaktadır.

\subsection{Kiralamalar}

\subsection{1. İcara Standardl}

Kelime anlamı bir varlığın kiraya verilmesi olarak tanımlanan icara İslami finansal kurulușlarda kullanılan finansman kullandırma yöntemlerinden biridir. Geleneksel bankacıllk sisteminden leasing'e karşıllk gelen icara İslam'ın ilk dönemlerinde de uygulamaları olan yöntemlerden biridir.

İcara işleminde varlığın mülkiyeti kiralama süresi sonunda kiralayana devredilir. Sermaye sahibi müşterinin talep ettiği özelliklere sahip malı satın alır ve üzerine belirli bir kâr payı eklemek suretiyle müşteriye kiralar (Yardımcıoğlu, 2016: 224)

Kiralama işlemlerini konu edinen İcâre ve İcâre Müntehiye Bittemlik standardı Faizsiz Finans Muhasebe Standartları (FFMS) 8 başlı̆̆ altında incelenmektedir. Katılım bankalarının veya faizsiz finans kuruluşunun kiraya veren ve kiracı olduğu durumlarda izlenmesi gereken prensipler bu standart kapsamında yer almaktadır

FFMS 8 İcara standardı kiralama işlemindeki giderleri, kazançları ve kayıplara dair muhasebe kurallarını düzenler. Faizsiz finans kuruluşunun kiraya veren veya kiracı olduğu durumda icare amaçlı edinen varlıklar, icar giderleri, hasılatı kazanç ve kayıpları da dâhil olmak üzere câre ve İcâre Müntehiye Bittemlîk'e ilişkin muhasebe kurallarını düzenler (KGK, FFMS 8, 2019: 1).

İcara sözleşmelerinde aşağıdaki şartlar gerçekleştiğinde icara işlemlerine ait muhasebe işlemleri yapılır (Hanif, 2016: 54).

Varlık kiracının kullanabileceği hale geldiğinde kiracıdan kira tahsil edilir. Varlık satıldığı takdirde ve kiralandığında iki ayrı sözleşme yapılır. İcara sözleşmesi, kullanım için 
teslim edilen varlığın süresi ile imzalanır ve satış sözleşmesi, mülkiyet devri ile imzalanır. Bunlarla beraber kiralayan birtakım yükümlülükleri vardır. Kiralayan kiracı için varlığın intifa'ını sürdürmelidir. Büyük bakım, yüksek tutardaki onarım maliyetlerini, olası riskler için bir sorumluluğu vardır (AOSSG, 2010: 73).

AAOIFI standartlarına göre icara aşağıdaki şekillerde sahipliğini aktarmaktadır (Atmeh \& Serdaneh, 2012: 4).

$\checkmark$ hediye yoluyla transfer

$\checkmark \quad$ sözleşmede belirlenen tutarla satışı yapılarak

$\checkmark$ kiralama süresinin bitiminden önce kalan fiyatın ödenmesi sonucu satışı sağlanarak

$\checkmark$ kiralanan varlığın kademeli olarak satışıyla

\subsubsection{Kiralamalar Standard}

İşletmeler, varlıklarını ya satın almak suretiyle ya da kiralama yoluyla elde edebilmektedir. $\mathrm{Bu}$ açıdan bakıldığında kiralama işlemi işletmelere bir finansman sağlamaktadır. Yeteri kadar fonu bulunmayan işletmeler faaliyetlerini yürütmek için varlıklarını kiralama yoluyla edinmektedir. Özellikle son yıllarda finansal kiralama şirketlerinin artan etkisi göz önüne alındığında oldukça önemli bir alternatif olmaktadır.

Muhasebe standartları tarafindan kiralama işlemlerine ilişkin olarak daha önce TMS 17 Finansal Kiralamalar standardı bulunmaktaydı. Bu standart kiralama işlemlerini finansal ve faaliyet kiralaması olarak ikiye ayırmakta ve finansal kiralama yoluyla elde edilen varlığın finansal tablolarda sunulmasına imkan vermekteydi (Aktaş, Kargın, \& Demirel Arıc1, 2017: 860 )

Ancak TFRS 16 Kiralamalar standardının uygulanmaya başlaması ile birlikte kiracılar için finansal ve faaliyet kiralaması ayrımı ortadan kalmıştır. Kiraya veren için ise bu ayrım korunmuştur. Bu durum hem finansal kiralama hem de faaliyet kiralaması yoluyla varlık edinen kiracıların bu varlıklarını finansal tablolarda sunabilmesini sağlamıştır. Bilindiği gibi kira sözleşmesinde tüm risklerin devredildiği kiralama türüne finansal kiralama, bunun dışındakilere de faaliyet kiralaması denilmektedir. Kiracı için bu durumun muhasebeleştirme açısından farklılık ortadan kalkmıştır.

Tablo 1. Kiracı Açısından TMS 17 ile TFRS 16'nın Karşılaştırılması

\begin{tabular}{|c|c|c|c|}
\hline & TMS 17 & TFRS 16 & FARK \\
\hline Sinıflandırma & $\begin{array}{l}\text { Finansal } \\
\text { Kiralama } \\
\text { Faaliyet } \\
\text { Kiralaması }\end{array}$ & $\begin{array}{l}\text { Tümü } \\
\text { Finansal } \\
\text { Kiralama }\end{array}$ & $\begin{array}{l}\text { Kiracı açısından bir } \\
\text { ayrım yapılmamakta } \\
\text { tümü finansal kiralam } \\
\text { olarak } \\
\text { değerlendirilmektedir. }\end{array}$ \\
\hline $\begin{array}{l}\text { Bilançoda } \\
\text { Gösterim }\end{array}$ & $\begin{array}{l}\text { Finasal } \\
\text { kiralama } \\
\text { bilançoda } \\
\text { gösterilir. } \\
\text { Faaliyet } \\
\text { kiralaması } \\
\text { dipnotlatrda } \\
\text { gösterilir }\end{array}$ & $\begin{array}{l}\text { Tüm } \\
\text { kiralamalar } \\
\text { Kiralama } \\
\text { maliyetleri } \\
\text { üzerinden } \\
\text { bilançoda yer } \\
\text { alır. }\end{array}$ & $\begin{array}{lr}\text { Faaliyet } & \text { kiralamaları } \\
\text { da } & \text { bilançoda } \\
\text { gösterilmektedir }\end{array}$ \\
\hline $\begin{array}{l}\text { Gelir } \\
\text { tablosunda } \\
\text { gösterim }\end{array}$ & $\begin{array}{l}\text { Kiralama } \\
\text { Giderleri } \\
\text { olarak yer } \\
\text { alır. }\end{array}$ & $\begin{array}{l}\text { Amortisman } \\
\text { ve kiralama } \\
\text { gideri olarak } \\
\text { yer alır. }\end{array}$ & 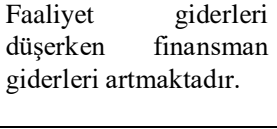 \\
\hline
\end{tabular}

Kaynak: (Aslan, 2018: 59)
TFRS 16'ya göre kiralanan bir varlık maliyet bedeli üzerinden muhasebeleştirilir. $\mathrm{Bu}$ maliyet bedeline, kira gideri ve kiracının başlangıçta katlandığı kiralanan varlığa ait taşıma, sökülme, restorasyon, montaj, konulacak yerin düzenlenmesi gibi giderler dahil edilir. Daha sonraki dönemlerde de standartta belirtilen durumlar hariç maliyet bedeli üzerinden ölçülmeye devam edilir.

\subsection{Ortaklıklar}

\subsubsection{Muşaraka ve Mudaraba Standartları}

\subsubsection{Muşaraka Standardl}

Kelime anlamı olarak ortaklık anlamına gelen muşaraka, faizsiz finans kuruluşlarının kullandığı yöntemlerden biridir. Bu ortaklık yönteminde tarafların ikisi de hem emek hem sermayeye ortak olmak suretiyle ortaklığı kurarlar. Faizsiz finans muhasebe standartlarının dördüncüsünde düzenlenen bu standart Müşâreke Finansmanı ismiyle Türkçeye çevrilmiştir. Söz konusu standartta müşareke finansmanı işlemlerinin finansal tablolara alınması, ölçümü ve açıklanmasına ilişkin esaslar yer almaktadır.

FFMS 4 Müşareke Finansmanı standardı kısa ve uzun vadeli ya da azalan Müşarake finansmanı işlemlerini inceler. $\mathrm{Bu}$ standart katılım bankasının Müşâreke sermayesindeki payını, münhasıran kendi fonlarından, kendi fonları ile kısıtlanmamış yatırım hesaplarının oluşturduğu birleştirilmiş fon havuzundan veya kısıtlanmış yatırım hesaplarından finanse etmiş olmasına bakılmaksızın uygulanır. Bu standart ayrıca katılım bankasının Müşâreke kâr veya zararlarındaki payıyla ilgili işlemlere de uygulanır (KGK, FFMS 4, 2019: 1).

Müşareke ortaklığında sermayeye olan katkı eşit veya farklı miktarlarda olabilmektedir. Kâr önceden kararlaştırılan oranlarda paylaştırılır. Aynı şekilde kayıp ve zararlarda önceden belirlenen oranlarda pay edilir. Sözleşmede belirlendiği şekliyle muşaraka yönetimine katılınabilmektedir (Mia, Hasnat, \& Mahjabeen, 2016: 67).

"Katılım bankasının Müşâreke sermayesindeki payı (nakit veya ayni olarak koyduğu), ortağa ödeme yapıldığında veya Müşâreke hesabında ortağın kullanımına hazır hale getirildiğinde finansal tablolara alınır. $\mathrm{Bu}$ pay, katılım bankasının kayıtlarında (müşterinin adıyla birlikte) Müşâreke finansmanı hesabının altında sunulur ve "Müşâreke Finansmanı" başlığı altında finansal tablolarda gösterilir. Katılım bankasının nakit olarak koyduğu Müşâreke sermayesindeki payı, ödenen tutar üzerinden veya Müşâreke hesabında ortağın kullanımına hazır hale getirilen tutar üzerinden ölçülür. Katılım bankasının ayni olarak koyduğu (ticari amaçla kullanılacak varlıklar veya teşebbüste kullanılacak parasal olmayan varlıklar) Müşâreke sermayesindeki payı, sermaye olarak konulan varlıkların gerçeğe uygun değeri (ortaklar arasında mutabık kalınan değeri) üzerinden ölçülür. Söz konusu varlıklar için yapılan değerleme, bunların gerçeğe uygun değerleri ile defter değerleri arasında bir fark olduğunu gösterirse, bu 
fark katılım bankasının kâr veya zararı olarak finansal tablolara alınır (KGK, FFMS 4, 2019: 3).

Ortak, tasfiye sonrasında veya hesabın sonlandırılması yapıldıktan sonra katılım bankasının kârlardaki muaccel hale gelen payını ödememişse, muaccel hale gelen söz konusu paylar ortaktan alacak olarak finansal tablolara alınır. Müşârekede ortağın ihmalinden ya da kusurundan dolayı zarara katlanılması durumunda, katılım bankasının bu tür zararlardaki payını ortak karşılar. $\mathrm{Bu}$ zararlar ortaktan alacak olarak finansal tablolara alınır (KGK, FFMS 4, 2019: 4).

\subsubsection{Mudaraba Standard}

Mudaraba standardı katılım bankalarınca gerçekleştirilen mudaraba finansmanına ilişkin işlemlerin finansal tablolara alınmasına ilişkin muhasebeleştirme esaslarını belirleyen standarttır.

İslam'dan önce de uygulanan ve İslam dininde de uygulanmasına onay verilen ortaklık türlerinden biri olan mudaraba, bir tarafın emeğini diğer tarafin da sermayesini ortaya koymak suretiyle kurdukları sözleşme türüdür. $\mathrm{Bu}$ ortaklıkta sermaye sahibine rabbu'l-mal, sermayeyi işletene de mudarib veya amil denmektedir. Mudaraba sözleşmesindeki asıl amaç kâr elde etmek ve bu kârı paylaşmaktır. Elde edilecek kâr sözleşme yapıldı anda belirlenen oranlara göre dağıtılabilmektedir. Esas nokta kârın muhakkak surette bölünüyor olması ve herhangi bir tarafin da kârdan mahrum kalmıyor olmasıdır (Çelik İ. , 2017: 381).

Faizsiz Finans Muhasebe Standartları 3 no'lu standartta incelenen Mudaraba standardi katılım bankasının fon sağlayıcı olarak gerçekleştirdiği Mudârebe finansmanı işlemlerine ve katılım bankasının Mudarebede kullanılmak üzere sağladığı sermayeye ilişkin işlemlere, söz konusu işlemlerin başlangıcından tamamlanmasına kadar geçen süreçte uygulanacaktır (KGK, FFMS 3, 2019: 3).

Mudârebe finansmanı, sermaye (nakdî veya aynî) Mudâribe ödendiğinde veya Mudâribin hesabına yazıldığında finansal tablolara alınır. Ayrıca Mudârebe sermayesinin taksitler halinde ödenmesinin kararlaştırılması durumunda her bir taksit ödemesi, ödeme zamanında finansal tablolara alınır. Mudârebe sözleşmesinin sona ermesinin gelecekte bir olayın meydana gelmesine bağ olmasının veya gelecekteki bir zamana ertelenmesinin söz konusu olması ve Mudârebe sermayesinin ödenmesinin söz konusu olayın meydana gelmesine veya söz konusu zamanın gelmesine bağlı olması durumunda; Mudârebe sermayesi sadece Mudâribe ödendiğinde finansal tablolara alınır. Mudârebe finansmanı işlemleri katılım bankasının finansal tablolarında "Mudârebe Finansmanı" başlığı altında sunulur. Parasal olmayan varlık şeklinde sağlanan Mudârebe sermayesi, "Parasal Olmayan Mudârebe Varlıkları" adı altında finansal tablolarda sunulur (KGK, FFMS 3, 2019: 3).

Tasfiyeden kaynaklanan zararlar Mudârebe sermayesi azaltılarak tasfiye sirasında finansal tablolara alınır. Mudârib kendisine ait kasıt veya kusurlardan kaynaklanan zararları üstlenir. $\mathrm{Bu}$ zararlar Mudâribden alacak olarak finansal tablolara alınır (KGK, FFMS 3, 2019: 5).

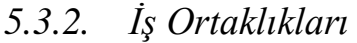

31 no'lu Uluslararası muhasebe standardı "İş Ortaklıklarındaki Paylar" standardı kaldırılmış ve bunun yerine ve bundaki bazı hükümleri de bünyesinde barındıran TFRS 11 "Müşterek Anlaşmalar" standardı yürürlüğe konmuştur.

AAOIFI standartlarında yer alan farklı ortaklık türlerine mukabil UFRS 11 "Müşterek Anlaşmalar" standard1 müştereken kontrol edilen müşterek anlaşmalarda payı olan işletmeler tarafinda kullanılan standarttır. Müşterek anlaşma iki veya daha fazla tarafin üzerinde müşterek kontrole sahip olduğu anlaşmadır (KGK, TFRS 11, 2019: $1)$.

Müşterek anlaşmaların yanı sıra 28 no'lu Uluslararası Muhasebe Standardı "İştiraklerdeki ve İş Ortaklıklarındaki Yatırımlar" standardı da ortaklıklar sonucu yapılan işlemlerin muhasebeleştirilmesine yönelik yayımlanan standartlardır.

\subsection{Fon Kullandırma}

\subsubsection{Murabaha}

İslami finansal sistemde kullanılan finansman yöntemlerinden biri olan murabaha literatürde fon kullandırma yöntemi olarak geçmektedir. Genel uygulaması katılım bankasının satın aldığı bir mala kârı da ekleyerek müşteriye satması şeklinde olmaktadır. Müşterinin finansmana ihtiyaç duyduğu bir anda katılım bankasından finansman kullanmasıyla başlayan bir süreç olduğundan fon kullandırma yöntemi olarak bilinmektedir. AAOIFI'nin yayınladığı "Murabaha ve Diğer Vadeli Alacaklar" standardı FFMS 28 no'lu standart olarak Türkçe'ye çevrilmiştir. FFMS 28 standardı murabahayı "malların maliyetinin üzerine anlaşılan bir kâr marjı eklenerek satılması" olarak tanımlamaktadır. Aynı şekilde satış bedelinin tek seferde veya vadeli olarak ödenebileceği de açıklanmaktadır.

FFMS 28'e göre murabahaya konu varlıkların muhasebeleştirilmesi aşağıdaki hususlara göre yapılmaktadır (KGK, FFMS 28, 2019: 3):

Stoklar, kuruluş ilgili stok üzerinde kontrole sahip olduğunda, diğer bir ifadeyle stokun mülkiyetinden kaynaklanan risk ve getirileri önemli ölçüde edindiğinde, kuruluşun finansal tablolarına alınır. Stokların parçalar halinde edinilmesinde de aynı şekilde finansal tablolara alınma işlemi yapılır. Stoklar, başlangıçta maliyeti üzerinden finansal tablolara alınır. Stok maliyeti, tüm satın alma maliyetlerini ve stokun mevcut konumuna ve durumuna getirilmesi için katlanılan diğer maliyetleri içerir.

Alacaklar FFMS 28' göre finansal tablolara alınmasında aşağıdaki hususlara dikkat edilir (KGK, FFMS 28, 2019: 3):

Ilgili stok Murabaha ya da vadeli satış sözleşmesi kapsamında satıldı̆̆ında, satıcı alacakları ve hasılatı finansal tablolarına alır. Alacak, itibari değeri (brüt tutar ya da fatura tutarl) üzerinden finansal tablolara alınır. 
Stokların sonraki ölçümlerde maliyet değeri ile net gerçekleşebilir değerinden düşük olanı üzerinden ölçülür. Brüt alacaklar sonraki ölçümlerde ödenememiş tutarlardan varsa kredi zarar karşılıkları düşüldükten sonra kalan tutar üzerinden ölçülür.

Stoklar satıldığında, kaybolduğunda veya çalındığında bunlarla beraber eskime, yıpranma vb. sebeplerle kullanılmaz hale geldiğinde veya alıcısının olmaması gibi durum olduğunda finansal tablo dışı bırakılacaktır. Alacaklar müşterinin borcunu ödemesi sonucu veya ödemeyeceği anlaşılıp tahsil edilemeyeceği kesinleşirse finansal tablolardan çıkarılır.

Temerrüt ve gecikmeli ödemeler karşılığında müşteri tarafindan verilen sadakalar, satıcının geliri olarak finansal tablolara alınmaz ve alındığında doğrudan ödenecek sadakalarda izlenir (KGK, FFMS 28, 2019: 7).

\subsubsection{Finansal Araçlar}

Finansal araçlar standardı farklı birkaç standart altında yayımlanmıştır. UFRS 7 Finansal Araçlar; Açıklamalar, UFRS 9 Finansal Araçlar, UMS 32 Finansal Araçlar; Sunum ve UMS 39 Finansal Araçlar; Muhasebeleştirme ve Ölçme standartları başlıklarıyla yayımlanmıştır.

UFRS 7 Finansal Araçlar; Açıklamalar standardının amacı şu şekilde belirlenmiştir:

\section{$\checkmark$ Finansal araçların işletmenin finansal durumu ve performansı açısından önemi ve \\ $\checkmark$ İşletmenin dönem içerisinde ve raporlama dönemi sonunda finansal araçlar nedeniyle maruz kaldığ 1 risklerin niteliği ve düzeyi ile işletmenin sözü edilen riskleri yönetme şekli}

gibi hususların kamuoyuna açıklanmasının sağlamaktır. Finansal tablo kullanıcılarının işletmenin finansal durum ve performansı açısından finansal araçların önemini değerlendirmelerine imkân veren bilgiler kamuoyuna açıklanır (KGK, TFRS 7, 2019: 1-2)

TMS 32 Finansal Araçlar; Sunum standartlarının kapsamında bu standardın tüm işletmeler tarafından tüm finansal araçlar için uygulanabilir olduğu açıklanmıştır. Bununla beraber bu standart, işletmenin beklenen alış, satış ya da kullanım gerekliliklerine uygun olarak finansal olmayan bir kalemin alınması veya teslimi amacı ile düzenlenmiş olan ve elde tutulmaya devam edilen sözleşmeler hariç olmak üzere, net ödemenin nakit ya da başka bir finansal araçla ya da finansal araç sözleşmesi gibi finansal araçların takası yoluyla yapıldığı finansal olmayan bir kalemin alım ya da satım sözleşmelerine uygulanır (KGK, TMS 32, 2019: 1).

TMS 32 Finansal Araçlar standardında geçen tanımlara göre finansal araç; Bir işletmenin finansal varlığı ile diğer bir işletmenin finansal borcunda ya da özkaynağa dayalı finansal aracında artışa neden olan herhangi bir sözleşmedir. Özkaynağa (Hisse senedine) dayalı finansal araç: İşletmenin tüm borçları çıkarıldıktan sonra varlıklarında bir payı/hakkı gösteren sözleşmedir. (KGK, TMS 32, 2019: 1).

Finansal araç tanımında geçen finansal varlık nakit veya başka bir işletmenin özkaynağına dayalı (başka işletmeden finansal varlık satın almak için düzenlenen sözleşme) finansal araçlardır. Finansal borç ise başka bir işletmeye finansal varlık verilmesi ya da takas edilebilmesi için düzenlenen sözleşmelerdir.

Finansal araç ya da finansal aracın bileşenleri ilk defa muhasebeleştirilirken sözleşmedeki düzenlemelerin özüne uygun ve finansal borç, finansal varlık ve özkaynağa dayalı finansal araç tanımlarıyla uyumlu bir sinıflandırma yapilır(KGK, TMS 32, 2019: 4).

Bir finansal araçla veya finansal borç niteliğindeki bir unsurla ilgili faiz, temettü, kayıp ve kazançlar, kâr ya da zararda gelir veya gider olarak muhasebeleştirilir. Özkaynağa dayalı finansal araç sahiplerine yapılan dağıtımlar doğrudan özkaynaklarda muhasebeleştirilir. Özkaynak işlemlerinden kaynaklanan işlem maliyetleri özkaynaktan indirim olarak muhasebeleştirilir (KGK, TMS 32, 2019: 10).

UFRS'ye göre murabaha; banka açısından bir finansal varlık olup buradan doğan gelirler faiz geliridir. $\mathrm{Bu}$ kapsamda düşünüldüğünde UFRS 15 no'lu standart hasılatın nasıl doğduğuna ilişkin açıklama yapmak yerinde olacaktır.

Müşterinin, varlığın mülkiyetine sahip olmaktan doğan önemli risk ve getirileri varlığın mülkiyetinden kaynaklanan önemli risk ve getirilerin müşteriye devri, müşterinin varlığın kullanımını yönetebildiğini ve varlığın kalan tüm faydasınıbüyük ölçüde elde edebildiğini gösterebilir. Ancak, taahhüt edilmiş bir varlığın mülkiyetinin getirdiği risk ve getirileri değerlendirirken işletme, varlığın devrine ilişkin edim yükümlülüğünden ayrı ilave bir edim yükümlülüğüne yol açan herhangi bir riski kapsam dışında bırakır. (KGK, TFRS 15, 2019: 7).

TFRS 15'e göre hasılatın doğması için önemli risk ve getirilerin karşı tarafa devredilmesi gerekmektedir. Bu bakımdan ufrsye göre murabaha tam bir satış işlemi olmayıp finansal varlık niteliği taşımaktadır.

İşletmenin, özkaynağına dayalı finansal araçlarını yeniden edinmesi durumunda, bu araçlar ("işletmenin geri satın alınan kendi hisseleri”) özkaynaktan düşülür. İşletmenin özkaynağına dayalı finansal araçlarının alışından, satışından, ihracından ya da iptalinden dolayı kar veya zarara herhangi bir kazanç ya da kayıp yansıtılmaz. Bunun gibi, işletmenin geri satın alınan kendi hisseleri, işletme tarafindan ya da konsolide edilmiş şirketler grubunun diğer üyeleri tarafindan geri alınabilir ya da elde tutulabilir. Alınan ya da ödenen tutarlar doğrudan özkaynakta muhasebeleştirilir.

\section{5. İnşaat Sözleşmeleri}

\subsection{1. İstisna Standardl}

Yapılmakta olan veya inşa edilmekte olan ya da inşa edilmesi gereken ürünlerin konu edildiği İslami finansman yöntemi istisna akdidir. Yapılacak veya tamamlanacak olan bina, araç, gemi, uçak vb. işlerin tamamlanmasında istisna' yöntemi tercih edilmektedir. İstisna' ve paralel istisna' ismiyle yayımlanan FFMS 10 no'lu standart istisna'dan kaynaklanan hasılat ve maliyetlerin muhasebeleştirilmesine rehberlik eden standarttır. 
İstisnâ maliyetleri şunları içerir (KGK, FFMS 10, 2019: 1)

$\checkmark$ Direkt maliyetler, özellikle Masnûnun (sözleşme konusu eserin) üretim maliyetleri ve

$\checkmark \quad$ Sözleşmeyle ilgili olan ve objektif şekilde dağıtılan endirekt maliyetler, genel yönetim giderleri, satış giderleri, araştırma ve geliştirme giderleri İstisnâ sözleşme maliyetlerine dâhil edilmez.

Alınan hakediş ödemeleri tutarı İstisnâ maliyetleri hesabı borçlandırılarak finansal tablolara alınır ve katılım bankasının finansal durum tablosunda varlıkların altında sunulur. Buna karşılık satıcıya İstisnâ borçları hesabı alacaklandırılır. Alınan varlıklar (sözleşme konusu eser) İstisnâ maliyetleri hesabına tarihi maliyeti (yani defter değeri) üzerinden kaydedilir. Alt İstisnâ varsa, sözleşme konusu eser alıcıya teslim edildiğinde, İstisnâ maliyetleri hesabının bakiyesi, alınan sözleşme konusu eserin niteliğini yansitan bir varlık hesabina aktarılır (KGK, FFMS 10, 2019: 6).

\subsubsection{Inşaat Sözleşmeleri}

Uluslararası finansal raporlama standartlarında yer alan "inşaat sözleşmeleri” standardı yürürlükten kaldırılmıştır. UMS 11 İnşaat sözleşmeleri standartları ile beraber UMS 18 Hasılat standardı da kaldırılarak bunların yerine 15 Ocak 2019'da UFRS 15 "Müşteri Sözleşmelerinden Hasılat" standardı yürürlüğe konmuştur.

"Müşteri sözleşmelerinden hasılat" standardında AAOIFI'nin istisna standardına karşılık gelen yalnızca aşağıdaki maddenin olduğu görülmektedir:

- Bir müşteri adına bir varlığın inşası, imali veya geliştirilmesi

$\mathrm{Bu}$ madde kapsamında söz konusu standart müşteriyle yapılan her bir sözleşmenin ayrı olarak muhasebeleştirilmesini öngörür.

Müşteri adına bir varlığın inşasında sözleşmenin tarafları sözleşmeyi onaylamış ve kendi edimlerini yerine getirmeye söz vermiş olur. İşletmece taahhüt edilen mal ve hizmetlerin devri karşılı̆̆ında işletme hak kazanmayı beklediği bedeli yansıtan bir tutar üzerinden hasılatı finansal tablolara yansitır. (KGK, TFRS 15, 2019: 1)

\section{Sonuç}

IASB farklı ülkelerde devam eden ticari işlemlerin muhasebe anlamındaki ortak dili fonksiyonunu son zamanlarda oldukça başarılı bir şekilde yerine getirmektedir. Bu anlamda KGK - IASB'nin yayımladığı standartları Türkçe'ye çevirmekte ve kamuoyunun görüşüne sunmakta ve daha sonra yayımlamaktadır. Zaman içerisinde çeşitli standartlar farklı sebep ve gerekçelerde birleştirilmekte, yürürlükten kaldırılmakta veya güncellenerek yeniden yürürlüğe girmektedir.

AAOIFI'nin 2010 yılında yayınladığ $\quad$ standartlar da IFRS'ye benzer şekilde İslami finansal kuruluşların ticari işlemlerde ortak dil mahiyetindeki standartlardır. $\mathrm{Bu}$ standartları Türkiye'de TKBB 2012 yılında Faizsiz Bankacılık Standartları (şeriat standartları) ismiyle yayımlamıştır. 2015 yılında AAOIFI'nin yayınladığ 1 standartlar ise 2018 y1lında Faizsiz Finans Standartları adıyla TKBB tarafindan Türkçeye çevrilmiştir. Bunların dışındaki muhasebe, denetim, yönetim ve etik standartlarını ise KGK çevirmeye başlamıştır. AAOIFI şu ana kadar 26 FFMS standardı yayımlamış, KGK bunun 18 ini Türkçeye çevirmiştir. Kalan 8'i kamuoyunun görüşüne açılmıştır.

Çalışmada AAOIFI ve UFRS'de yer alan seçilmiş standartların karşılıklı olarak incelenmesiyle elde edilen sonuçlar tablo halinde aşağıdaki gibi özetlenmiştir.

\begin{tabular}{|c|c|c|}
\hline & AOIFI & FRS \\
\hline $\begin{array}{l}\text { Kavramsal } \\
\text { Çerçeve } \\
\text { (Amaç) }\end{array}$ & $\begin{array}{l}\text { Kullanıcılara sunulan } \\
\text { çeşitli bilgiler arasından } \\
\text { istediklerini } \\
\text { seçmelerine } \\
\text { tanınması imkân }\end{array}$ & $\begin{array}{l}\text { Finansal tablolarda } \\
\text { yer alacak bilgilerin } \\
\text { karşılaştırılabilir } \\
\text { olmasını sağlamak }\end{array}$ \\
\hline $\begin{array}{l}\text { Kiralamalar } \\
\text { İcara - } \\
\text { Kiralamalar }\end{array}$ & $\begin{array}{l}\text { Varlık kiracının } \\
\text { kullanabileceği hale } \\
\text { geldiğinde kiracıdan } \\
\text { kira tahsil edilir. }\end{array}$ & $\begin{array}{l}\text { Varlık maliyet } \\
\text { bedeli ile kiralanır }\end{array}$ \\
\hline $\begin{array}{l}\text { Ortaklıklar } \\
\text { Muşaraka - } \\
\text { İş } \\
\text { Ortaklıkları }\end{array}$ & $\begin{array}{l}\text { İki taraf hem emek hem } \\
\text { sermaye ile ortaklıga } \\
\text { katılır. }\end{array}$ & $\begin{array}{l}\text { İki veya daha fazla } \\
\text { tarafin müșterek }\end{array}$ \\
\hline $\begin{array}{l}\text { Ortaklıklar } \\
\text { Mudaraba - } \\
\text { İş } \\
\text { Ortaklıkları } \\
\end{array}$ & $\begin{array}{l}\text { Bir taraf emegini bir } \\
\text { taraf sermayesini ortaya } \\
\text { koyarak ortaklık kurar. }\end{array}$ & \\
\hline $\begin{array}{l}\text { Fon } \\
\text { Kullandırma } \\
\text { Murabaha - } \\
\text { Borçlanma } \\
\text { Maliyetleri } \\
\end{array}$ & \multirow{2}{*}{$\begin{array}{l}\text { Temerrüt ve gecikmeli } \\
\text { ödemeler karş1lı̆ıında } \\
\text { alınan sadakalar gelir } \\
\text { olarak kaydedilmez. } \\
\text { "Doğrudan ödenecek } \\
\text { sadakalar"da izlenir. }\end{array}$} & $\begin{array}{lr}\text { Borçlanma } & \\
\text { maliyetleri } & \\
\text { doğrudan } & \text { dönem } \\
\text { gideri } & \text { olarak } \\
\text { kaydedilir. } & \\
\end{array}$ \\
\hline $\begin{array}{l}\text { Fon } \\
\text { Kullandırma } \\
\text { Murabaha - } \\
\text { Finansal } \\
\text { Araçlar }\end{array}$ & & $\begin{array}{lr}\text { Finansal } & \text { araçların } \\
\text { işletmenin } & \text { finansal } \\
\text { durumu/performans1 } \\
\text { açısından } & \text { önemi } \\
\text { kamuoyuna } & \\
\text { açıklanır. } & \end{array}$ \\
\hline $\begin{array}{l}\text { İnşaat } \\
\text { Sözleşmeleri }\end{array}$ & $\begin{array}{lr}\text { Alınan } & \text { hakedişler } \\
\text { istisna } & \text { maliyetleri } \\
\text { hesabı } & \text { borçlandırılmak }\end{array}$ & $\begin{array}{l}\text { Bir varlık inşasında } \\
\text { sözleşmenin } \\
\text { tarafları sözleşmeyi }\end{array}$ \\
\hline $\begin{array}{l}\text { İstisna } \\
\text { İnşaat } \\
\text { Sözleşmeleri }\end{array}$ & $\begin{array}{l}\text { suretiyle } \\
\text { varlıkların } \\
\text { gösterilerek fintında } \\
\text { tablolara alınır. }\end{array}$ & $\begin{array}{l}\text { onaylar ise beklenen } \\
\text { tutar finansal } \\
\text { tablolara alınır. }\end{array}$ \\
\hline
\end{tabular}

Kaynak: Yazar(lar) tarafından hazırlanmıştır.

Finansal işlemlerin oldukça önemli bir kısmı geleneksel bankacıllk sistemi vasıtasıyla gerçekleşmektedir. Katılım bankalarının bütün bankacılık sistemindeki payı yakın geçmişte \% 5 idi. Katılım bankalarının farklı opsiyonlar sunmasıyla faizsiz sistemi tercih eden kitlede bir artış görülmeye başlanmıştır. KGK'nın katılım bankaları ve faizsiz finans alanındaki uzmanlarla ortak çalışması ve bu anlamda çeşitli tanıtımlar yapması katılım bankaları, tüm bankacılık sektöründeki payını artıracaktır.

Katılım bankalarının geleneksel bankalardan bazı farklı çalışma yöntemleri bulunmaktadır. UFRS'ye göre yapılacak raporlamalarda finansal bilgi kullanıcılarına tamamen İslami prensiplere göre hazırlanmış bilgiler 
sunulmamış olacaktır. $\mathrm{Bu}$ nedenle AAOIFI muhasebe standartlarının kullanılması daha anlamlı olacaktır. Katılım bankalarının 1 Ocak 2020 itibariyle ihtiyari olarak tablolarını AAOIFI'ye göre hazırlamalarına olanak sağlanmıştır. Katılım bankaları ihtiyari olarak değil bir zorunluluk ilkesiyle raporlamalarını AAOIFI'ye göre yapmaları halinde katılım bankaları arasında bir uygulama birliği sağlanmış olacaktır. Dahası bu uygulama birliği dünyadaki katılım bankalarıyla ve özellikle İslam ülkelerindeki katılım bankalarıyla sağlanacağı da bu hususu ayrıca önemli kılmış olacaktır. Bu vesile ile Türkiye'deki katılım bankaları katılım bankacılığı anlamında uluslararasılaşma yolunda önemli bir adım atmış olacaktır.

\section{Kaynakça}

AAOIFI. (2019). About AAOIFI. 11 06, 2019 tarihinde http://aaoifi.com/our-history/?lang=en adresinden alınd 1

AAOIFI. (2020). About AAOIFI. 11 06, 2019 tarihinde http://aaoifi.com/our-history/?lang=en adresinden alınd 1

Abdel-Karim, R. A. (1999). Accounting and Auditing Standards for Islamic Financial Institutions. Proceedings ofo the Second Harvard University Forum on Islamic Finance: Islamic Finance into the 21 st Century (s. 239-241). Cambidge : Harvard University.

Ağkan, F. (2016). AAOIFI Standartları ve Türkiye Katılım Bankalarında Uygulanabilirliği. Anemon Muş Alparslan Üniversitesi Sosyal Bilimler Dergisi, 235243.

Akgün, A. İ. (2013). Uluslararası Finansal Raporlama Standartlarının Finansal Analize Etkisi: IMKB'ye Yönelik Bir Araştırma. Doguş Üniversitesi Dergisi, 14(1), 10-26.

Aktaş, R., Kargın, S., \& Demirel Arıcı, N. (2017). Yeni Kiralamalar Standardı UFRS 16'nın Getirdiği Yenilikler ve İşletmelerin Finansal Tablolarına ve Finansal Oranlarına Olası Etkilerinin Değerlendirilmesi. İşletme Araştırmaları Dergisi, 9(4), 858-881.

Aktepe, İ. E., \& Odabaşı, M. (2012). Faizsiz Bankacılık Standartları. İstanbul: Türkiye Katılım Bankaları Birliği.

AOSSG. (2010). Financial Reporting Issues relating to Islamic Finance. Mart 7, 2020 tarihinde http://www.aossg.org/docs/AOSSG_IF_WG-

Research_Paper_110ct2010.pdf adresinden alınd 1

Aslan, Ü. (2018). UFRS 16 Kiralamalar Standard Kapsamında Faaliyet Kiralamasının Kiracı İşletme Tarafindan Muhasebeleştirilmesi ve Raporlanması. Muhasebe ve Finansman Dergisi(77), 55-68.

Atmeh, M. A., \& Serdaneh, J. (2012). A Proposed Model for Accounting Treatment of Ijarah. International Journal of Business and Management, 7(18), 49-56.
Aysan, M. (2007). Uluslararası Finansal Raporlama Standartları ve Küresel Uyum. 1. Balkan Ülkeleri Uluslararası Muhasebe ve Denetim Konferansi (s. 51-56). Edirne: MUFAD.

CIO-Wiki. (2019). International Accounting Standards Board (IASB). Kasim 19, 2019 tarihinde Cio Index: https://cio-

wiki.org/wiki/International_Accounting_Standards_ Board_(IASB) adresinden alındı

Çelik, İ. (2017). Meşru' Bir Yatırım Aracı Olarak Mudarebe ve Günümüzde Kullanımı. INJOSOS Al- Farabi International Journal on Social Sciences, 1(3), 381395.

Çelik, Y., \& Turan, Z. (2019). Yeni Kavramsal Çerçevenin Finansal Raporlama Açısından İncelenmesi. Uluslararası Muhasebe Ve Finans Araştırmaları Dergisi, 1(1), 91-106.

Çemberlitaş, İ. (2019). AAOIFI Ve UFRS'ye Göre Teverruk Uygulamasi, Muhasebeleştirilmesi Ve Raporlanmast. Malatya: İnönü Üniversitesi Sosyal Bilimler Enstitüsü (Yayımlanmamış Doktora Tezi).

Deloitte. (2019). Uluslararasl Finansal Raporlama Standartları (UFRS) Sunum ve Açılama Kontrol Listesi. Kasim 19, 2019 tarihinde Verginet: https://www.verginet.net/dtt/1/UFRS-SunumAciklama-Kontrol-Listesi.aspx adresinden alındı

Erkuş, H., \& Çenberlitaş, İ. (2016). İslami Finansal Araçlardan Olan Sukukların Muhasebeleştirilmesi. Dicle Üniversitesi Iktisadi ve İdari Bilimler Fakültesi Dergisi, 245-262.

Ersoy, M., Çatıkkaş, Ö., \& Yatbaz, A. (2018). İslami Muhasebenin Gelenesek Muhasebe ile Karşılaştırmalı Olarak İncelenmesi. Uluslararası İslam Ekonomisi ve Finans Araştırmaları Dergisi, 95-109.

Hanif, M. (2016). Ijarah Accounting: A Comparison of Conventional IAS-17 and Islamic FAS-8. Journal of Islamic Economics, Banking and Finance, 12(1), 49-63.

http://aaoifi.com/structure/?lang=en. (tarih yok).

IFRS. (2019). Who We Are. Kasim 19, 2019 tarihinde IFRS: https://www.ifrs.org/about-us/who-weare/\#about-us adresinden alınd 1

KGK. (2011). Finansal Raporlamaya Ilişkin Kavramsal Çerçeve. Kamu Gözetimi Muhasebe ve Denetim Standartları Kurumu: https://www.kgk.gov.tr/Portalv2Uploads/files/Dyna micContentFiles/T\%C3\%BCrkiye\%20Muhasebe\%2 0Standartlar\%C4\%B1/TMSTFRS2019Seti/Finansal \%20Raporlamaya\%20\%C4\%B0li\%C5\%9Fkin\%20 Kavramsal\%20\%C3\%87er\%C3\%A7eve/Kavramsal $\% 20 \% \mathrm{C} 3 \% 87 \mathrm{er} \% \mathrm{C} 3 \%$ A7eve.pdf adresinden alınmıştır

KGK. (2018). Kavramsal Çerçeve. Kamu Gözetimi Muhasebe ve Denetim Standartları Kurumu. 
KGK. (2019). AAOIFI Kavramsal Çerçeve. Ankara: Kamu Gözetimi Muhasebe ve Denetim Standartları Kurumu.

KGK. (2019). Faizsiz Finans Kuruluşlarının Finansal Raporlamasına İlişkin Kavramsal Çerçeve. Kasım 20, 2019 tarihinde Kamu Gözetimi Muhasebe ve Denetim Standartlar1 Kurumu (KGK): https://www.kgk.gov.tr/Portalv2Uploads/files/PDF\% 20linkleri/standartlar\%20ve\%20ilke\%20kararlar\%C 4\%B1/FFMS/Faizsiz\%20Finans $\% 20$ Kurulu $\%$ C5\%9 Flar\%C4\%B1n\%C4\%B1n\%20Finansal\%20Raporla mas\%C4\%B1na\%20\%C4\%B0li\%C5\%9Fkin\%20Ka vramsal $\% 20 \% \mathrm{C} 3 \% 87 \ldots$ _.pdf adresinden alınd 1

KGK. (2019). Faizsiz Finans Muhasebe Standardı 8 İcâre ve İcare Müntehiye Bittemlîk. Ankara: Kamu Gözetimi Muhasebe ve Denetim Standartları Kurumu.

KGK. (2019). TMS/TFRS ve TMS/TFRS Yorumlart Nedir? 10 01, 2019 tarihinde KGK-Kamu Gözetimi Muhasebe ve Denetim Standartları Kurumu: https://www.kgk.gov.tr/DynamicContentDetail/6651 /TMS/TFRS-ve-TMS/TFRS-Yorumlar\%C4\%B1nedir? adresinden alındı

Mia,, M. R., Hasnat,, M. A., \& Mahjabeen, W. (2016). Mudharabah and Musharakah from the accounting perspective by referring to AAOIFI, IFRS and MFRS. IOSR Journal of Business and Management, 67-72.
Özulucan, A., \& Deran, A. (2009). Katılım Bankacılı̆̆ı ile Geleneksel Bankaların Bankacılık Hizmetleri ve Muhasebe Uygulamaları Açısından Karşılaştırılması. Mustafa Kemal Üniversitesi Sosyal Bilimler Enstitüsü Dergisi, 85-108.

SlidePlayer. (2015). Finansal Raporlama Standartlart ve Uygulamalart. Kasim 20, 2019 tarihinde Slide Player: https://slideplayer.biz.tr/slide/2903605/ adresinden alınd 1

Trimble, M. (2017). The Historical and Current Status of IFRS Adoption around the World. University of Mannheim.

UFRS/IFRS. (2015). Avrupa Birliği ülkelerinde UFRS gelişimi. Kasım 19, 2019 tarihinde UFRS / IFRS / TFRS Hayatımızda: http://ufrsifrs.blogspot.com/2015/02/avrupa-birligiulkelerinde-ufrs-gelisimi.html adresinden alındı

Üstünel, B. (2003). Türkiye Muhasebe Standartları Kurulu ve Ulusal Finansal Raporlama Standartlart. 10 03, 2019 tarihinde http://archive.ismmmo.org.tr/docs/SEMPOZYUML AR/SEMPOZYUM_06/5Oturum/BulentUstunel.pdf adresinden alınd 1

Yardımcıoğlu, M. (2016). İcare (Finansal Kiralama) İşlemlerinin İslami Muhasebe Standartları Çerçevesinde İncelenmesi. Journal of Social and Humanities Sciences Research, 224-233. 